\title{
12 Geographic Agency
}

\author{
Iran as a 'Civilizational Crossroads' in the Belt and Road \\ Geography
}

Mohammadbagher Forough

\begin{abstract}
Chapter 12 focuses on Iran and tackles two issues. First, it seeks to demarcate the conceptual boundaries of 'geographic agency'. Second, it attempts to apply this concept to the case of Iran. Adopting a critical geography approach, the chapter unpacks how Iran is reinventing itself geographically through certain 'space-making processes' and 'space-framing assumptions'. The chapter argues that Iran is showing agency at three geographical levels: 1) as a nation state, it is systematically representing the 'idea of Iran' as a 'civilizational crossroads'; it does so 2) in a region that the Iranian government chooses to call 'West Asia' (and not 'the Middle East'), and 3) in an emergent world whose organizing trope is a 'New Silk Roads' imaginary and which has a geoeconomic rather than geopolitical logic.
\end{abstract}

Keywords: Belt and Road Initiative, Iran, geographic agency, Silk Roads, China, civilizational crossroads

If the twentieth century was defined mostly by geopolitics and mostly by Western actors, this century is being defined increasingly by geoeconomic processes mostly instigated through the agency of Asian actors such as China, India, and others. ${ }^{1}$ If the previous century was about establishing Westphalian political borders to separate nation states, this century is increasingly about how infrastructure can create further 'connectivity' among economies, cultures, and peoples. This connectivity brings both

1 This is not to say that the former century lacked geoeconomics or the current one lacks geopolitics.

Schneider, Florian (ed.), Global Perspectives on China's Belt and Road Initiative: Asserting Agency through Regional Connectivity. Amsterdam, Amsterdam University Press 2021 DOI: 10.5117/9789463727853_CH12 
opportunities and risks (such as the current pandemic, COVID-19). The Chinese Belt and Road Initiative (BRI) is currently the most forceful and the only truly global initiative in the world in terms of the economic, diplomatic, and discursive momentum that it has created. However, the BRI is not the only initiative and China is not the only actor showing such agency. The International North-South Transport Corridor (INSTC) aims to link India via Iranian land to Russia, Central Asia, and Europe. The Russian initiative, the Eurasian Economic Union (EAEU), aspires to geoeconomically (re) connect the former geography of the Soviet Union. Finally, the Ashgabat Agreement aims to connect Central Asia to international waters via Iran and the Persian Gulf.

A new geographic imaginary and global centre of gravity is emerging. This new centre has been described as 'Asia', 'new continentalism in Eurasia' (Calder 2012), 'Afro-Eurasia' (Frankopan 2015), or the 'East' leading to the 'Easternization' (Rachman 2017) of global geography. No matter which trope one adopts, West Asia or the Middle East plays a significant role in it. Its role is considerable for a host of important reasons and processes, which include global energy (production, transit, pricing, and conflicts), refugees, Persian Gulf security, nuclear non-proliferation, political Islam, non-state actors (such as Hezbollah and Hamas), the Israeli-Palestinian conflict, civil wars (such as that in Syria), regional tensions (such as the Saudi-Iranian rivalry), the Chinese BRI, the International North-South Transport Corridor, the Ashgabat Agreement, the Russian Eurasian Economic Union, as well as others.

Iran, which is centrally located at the heart of West Asia, is in one way or another deeply enmeshed in all these geoeconomic and geopolitical processes in the region and beyond. More often than not, the academic literature focuses on Iran only geopolitically. This chapter aims to address this gap in the literature by focusing on Iran's role in Eurasian geoeconomics. The questions that this chapter aims to address are 1) How is Iran adapting to the geoeconomic shifts unfolding in Eurasia, especially the rise of actors such as China and the advent of the BRI? and 2) How is Iran reimagining its 'place' and the place of its region in global geography? Adopting a critical geography perspective, which views geography as simultaneously both material and ideational, this chapter aims to address these questions by doing an analysis of both the ideational developments (the discursive developments) and the material developments (the policies and infrastructure processes) in which Iran is engaging.

The overall argument of this chapter is that in the context of contemporary geoeconomic processes, Iran is showing geographic agency by actively 
engaging in geoeconomic processes that are transforming not only global and regional geography but also Iranian national self-perceptions. Under contemporary conditions, Iran is geographically reimagining itself at three levels: Globally, Iran views the contemporary world in terms of the rise of 'the East', rise of Asia, and particularly in terms of the rise of the (New) Silk Roads, hence its 'turn to the East'. Regionally, it is articulating its preference for the concept of 'West Asia' to replace 'the Middle East', which it views as Eurocentric. Nationally, Iran is reimagining itself as a 'civilizational crossroads' between various economies, peoples, and civilizations. The three geographic reimaginings are deeply interlinked with each other and deeply rooted in Iranian history. In terms of the BRI, Iran is increasingly becoming integral (if not indispensable) to the China-Central Asia-West Asia (CAWA) Corridor.

The argument laid out above will unfolded in this chapter as follows: Section 2 will introduce the concept of geographic agency. Section 3 will briefly review the literature on the changing 'idea of Iran'. Section 4 will examine Iranian geographic assumptions about the rise of the New Silk Roads, the Iranian policy of 'turning to the East', and its preference for 'West Asia' as the name of the region. Then Section 5 will unpack Iran's new geoeconomic self-perception, what I call 'Iran as a civilizational crossroads' with its concomitant policies of port modernization and railway upgrade. This will be followed by a conclusion.

\section{Geographic Agency}

This section demarcates the conceptual boundaries of what I call geographic agency. First, geography. Traditionally, in the humanities, geography has been understood in terms of 'absolute space' that is rooted in Newtonian physics. In this conception, absolute space is understood, according to Harvey (2006: 121), as an absolute 'pre-existing and immovable grid amenable to standardized measurement and open to calculation'. The field of international relations (IR) has not been an exception to this rule. It has also suffered from such problematic 'geographical assumptions', including the 'territorial trap' of sovereignty (Agnew 1994), or what Larkins (2010) calls the 'territorial apriori [sic]'. These are assumptions that render IR state-centric (Guzzini \& Leander 2006), Eurocentric and ahistorical (Van der Pijl 2007), and West-centric (Bilgin 2010).

Critical geography aims to avoid such problematic assumptions by conceiving of geography as both ideational and material. Like many other 
critical schools of thought, it was a brainchild of the late 1960s and early 1970 on and was a response to the major issues of the time. These were issues such as the rise of civil rights and student movements, environmental movements, and the Vietnam War (Peet 200o). Traditional geography, according to Peet (ibid.), was part of a conservative shift in Enlightenment thinking in the late nineteenth century. Spatial science could be progressive only in the sense of 'social engineering rather than the organic sense of social transformation' (ibid.: 951). Critical or radical geography became critical of positivist schools of thought and methodologies. It went through several transformations that brought under its umbrella various critical schools of geography, such as Marxism, feminism, poststructuralism, postmodernism, and discourse analysis. Critical geography aims to approach the question of space as a dynamic process that both constructs and constrains social, political, and economic processes and is simultaneously constructed and constrained by them. It aims to remain socially and politically relevant, to uncover hegemonic arrangements, geographies of resistance, fears and hopes, and unpack (in)justices and power relations that are often hidden in geographic representations.

More specifically, this chapter will draw on the theoretical work of Matthew Sparke. He focuses on the hidden hyphen in the word 'geo-graphy', calling for a 'persistent examination in terms of acknowledging how the 'geo' of any particular geography is 'graphed', that is to say, produced, by multiple, often unnoticed, space-making processes and space-framing assumptions (Sparke 2007:338). The main objective of this chapter is to investigate these 'processes' (material geography) and 'assumptions' (ideational geography) that are at work in Iranian geographic agency.

What of agency? And how does it play into geography? Critical geography argued that traditional notions of geography and spatial thinking were themselves instruments of hegemonic power and oppression. These notions took agency away from oppressed actors and populations and represented them in a reductionist or negative manner, or simply did not represent them. Critical geography is more interested, as mentioned above, in doing justice to local representations and 'organic social transformations'. Part of such organic social transformations, I would argue, is the ability of actors to have agency over geographic matters and to define their own place in the various spaces of global geography. For the purposes of this chapter, geographic agency can be defined in a twofold fashion. Ideationally, it is the discursive ability of an actor (such as a group of people, an individual, or an organization) to define, articulate, and (rep)present themselves and their place (their identities, fears, and aspirations) in the world geographically; 
practically, geographic agency can be defined as the ability of the said actor to act in the world (through actions and implementing policies) to materialize their geographic discourse and self-representations. The two dimensions are inextricably interlinked.

Regarding methodology, the following approaches have been taken. To examine the ideational aspect (or 'space-framing assumptions'), the discourses of Iranian official outlets have been analysed to examine how Iran is geographically reimagining itself. Such outlets include announcements, policy documents, and policy speeches by the Iranian leader, Ayatollah Khamenei, the Iranian President (Hassan Rouhani), the Iranian Foreign Ministry, the Ministry of Transportation, and the Iranian Railways (RAI). They also include some (semi)official news outlets. For the material aspect (or space-making processes and policies), the chapter draws on the knowledge gained by the author during years of attending global academic workshops and conferences related to the topic (in both China and Iran), and attending think tank events about the topic in several countries. It also draws on eight field trips that the author has made to Iran in the last five years in order to investigate its role in the BRI and other initiatives. These include three recent trips that were made in late 2019 and 2020 specifically to gain the latest updates and carry out interviews to be included in this chapter. The recent field research included visits to the Iranian capital of Tehran to conduct semi-structured interviews with academics and policymakers in institutions including the Eurasia Center at Tehran University, the Chamber of Commerce, the Foreign Ministry, Boushehr (to investigate China's interests in Iranian energy resources), and Chabahar Port (to investigate Chinese and Indian interests in the International North-South Transport Corridor).

\section{'The Idea of Iran'}

This section offers a brief review of the literature about what Gnoli (1989) called 'the idea of Iran' and some of the momentous changes in the Iranian self-perception throughout history. Since their conception, terms such as 'Iran' and 'Iranians' have been contested concepts. Their meaning has been debated throughout the civilization's long history, a history of dominating, occupying, and traumatizing the region as well as being dominated, occupied, and traumatized by the forces of the region and beyond. The ebbs and flows of Iranian history show 'the remarkable resilience of the idea of Iran' (Axworthy 2008: xi). What is this idea? 
The agricultural settlements or villages in what is today Iran have been traced back to at least the sixth millennium BCE' (see Berkowitz 1996; Axworthy 2008). However, most of the Iranian popular and official discourse starts the historical narrative with the Achaemenid Empire (c. 550-330 BCE), the so-called First Persian Empire, founded by Cyrus. Since its advent, a foundational question has been what to name its geography and the rich diversity of its multinational state. The Achaemenid inscriptions did not define their kingdom in a geographic or ethnic sense (Gnoli 1989: 6). This was natural as the idea of the empire meant the whole globe (ibid.). Cyrus defined himself as 'the King of Kings'. Later emperors referred to themselves as 'the king of lands', 'king of the peoples', or the 'king of this (far-reaching) earth' (Gnoli 1989: 6-7). This empire, Gnoli argues, can be best known as the 'earth-empire' (ibid.: 7). Alexander put a brutal end to it, but the idea of this empire survived through absorbing Hellenistic culture and administration.

The idea of Iran returned with the Sassanian Empire (224-651 CE), this time with a more formulated agenda for territorial and political demarcation. This empire tried to create a systematic history and a definition of the medieval Iran. The word Iran is derived from èrān, the first existing record of which dates back to the investiture reliefs of Ardashir, the founder of Sassanian Empire. The geographic space that these people occupied came to be called 'Iranshahr' or the land or 'empire of the Iranians'. Anērān meant those subjects, peoples, and provinces that were part of the Iranian empire (such as present day Cappadocia, Syria, and Egypt) but whose peoples were not considered to be of Iranian identity. Little by little, èrān took on a geographic dimension and meant the land of Iranians. This obviously came into effect through imperially 'overwhelming the indigenous populations politically, linguistically, and culturally' (Malandra 2005: 116).

The Iranian narrative or myth of origin, and the sense of Iranian nationalism for many Iranians today, is rooted in these two pre-Islamic empires. In terms of physical geography, these two empires occupied and spread Iranian influence in the area between the Mediterranean Sea and the Indus River. They built major infrastructure projects that connected various parts of the empire. The most famous of these projects was the Royal Road built by Darius in the fifth century BCE, which was one of the first transcontinental highways, so to speak, built in global history, spanning from the south of Iran to present day Turkey (back then part of Achaemenid Empire). These infrastructure projects together with the state security provided by these two empires contributed immensely to the advent and operation of what we call the ancient Silk Roads geography. The Sassanians controlled much of Western Asia until it fell to the emergent Islamic Empire that began the Islamization of the country. 
Iran survived this invasion and absorbed the new ideas of Islam. Arab conquerors became Persianized (Canfield 2002: 4). Zoroastrianism did not survive as the state religion and Iran was Islamicized. Islam was partly Iranicized as well. After the Arab rule of Iran, the Samanid Empire (819 to 999) came to power, the first Iranian empire to rise after the invasion. The empire's religion was Sunni Islam, but it was tolerant of Shia Islam (Daniel 2012). It became independent of Arab rule and revived the Farsi language and culture, and with that the idea of Iran as an empire. This empire is regarded in today's scholarship as part and parcel of the 'Turko-Persian Islamicate culture', which is defined as an 'ecumenical mix of Arabic, Persian, and Turkic elements that melded in the ninth and tenth centuries in eastern Iran' and was carried 'to neighbouring areas, so that it eventually became the predominant culture of the ruling elite classes of West, Central and South Asia' (Canfield 2002: 1). Canfield goes on to write that the 'underlying stratum from which Turko-Persian Islamicate culture sprang was Persian'. This Persian stratum was rooted in the Achaemenid and Sassanian Empires (ibid.) and the material and ideational infrastructure they had built in the region.

Later dynasties further redefined Iran. The Safavids (1501-1736) converted the country to Twelver Shia Islam, which is the foundation of the contemporary official religious identity of the country. Other changes include the conquest of Iran by the Mongols between 1219-1221 (who also became Persianized), the invasion by Tamburlaine in 1383 (whose empire was also Persianized), and the conquest of India by the Iranian Nader Shah (1736-1747). Then there is also the idea of constitutional monarchy, which Iranians got from Europeans during the Qajar dynasty (1789-1925), the turn back between 1925 and 1935 to the absolutist dictatorship of the Pahlavi dynasty (a close ally of the West), and once again the return to political Islam with the 1979 revolution. To sum up, Iranian geography has always been a malleable heterogeneous repertoire of identities. As I will show in the next sections, the current Iranian ruling elites resort to both Islamic and pre-Islamic parts of Iranian history in order to make geographic and historical sense of the position of the country in the world today. The idea of Iran has always been creatively and conveniently (mis)read, (re)made, and revised by Iranians at moments of great strength or great weakness, as well as at moments of change such as our contemporary era. Selden (2013: 143) argues that 'creative mythmaking [...] has always served progressively to consolidate the identity of Iran'. Along the same lines, Axworthy (2008:12) rhetorically asks:

If [...] the centre of Iranian culture had moved at different times from Fars in southern Iran to Mesopotamia, to Khorasan in the north-east and 
Central Asia, and to what is now called Azerbaijan in the north-west; and given its strong influence far beyond the land of Iran itself, into Abbasid Baghdad and Ottoman Turkey for example on the one side and into Central Asia and Moghul India on the other, and beyond; then perhaps we should set aside our usual categories of nationhood and imperial culture and think instead of Iran as an Empire of the Mind?

In the following sections, I will unpack the ways in which the emergence of new Asian geoeconomic initiatives in general and the BRI in particular have impacted the idea of Iran.

\section{Iran Reimagining Global and Regional Geography}

Iranian geographic agency manifests itself most broadly at the global or continental level in actively promoting the revival of 'Silk Roads geographic imaginary', as well as presenting the rise of Asia or 'the East' (as a spaceframing assumption) and the 'turn to the East' strategy (as a space-making process or official policy). This section will argue that both the 'imaginary' and the 'turn' had already been at the heart of the Iranian official geographic discourse before the advent of the BRI. However, these have found clear unmistakable discursive, material, infrastructural, and policy expressions with the emergence of the BRI and other initiatives. At the regional level, Iranian officials are articulating their unmistakable preference for the geographic concept of 'West Asia' over 'the Middle East'.

\section{Iran Promoting the Revival of Silk Roads}

First, a caveat. There is a tendency in global mass media and even among some experts to associate the ancient Silk Roads with China (as if they were a highway between Rome and Beijing) and also to associate the new Silk Roads with China's BRI. Both accounts are simplistic and false. The ancient Silk Roads were 'not an actual road, but a stretch of shifting unmarked paths across massive' geographies of Afro-Eurasia (Hansen 2012: 5), hence the plural concept of 'Roads' used in this chapter. Nor is the idea of New Silk Roads a Chinese concept. The discourse has been alive and well in Iran, and in other countries in Asia, especially Central Asia, since at least the 1990 s.

Khamenei, who has been the Iranian leader since 1989, has been promoting this idea for a long time. In his 2009 meeting with Abdullah Gul, then Turkish president, Khamenei talked about how 'Iran and Turkey are capable 
of reviving the Silk Road' (Khamenei 2009). Khamenei's 2009 remarks about reviving the Silk Road is evidence of how the discourse of Silk Roads existed long before the BRI. It is not far-fetched to trace this idea back to TurkoPersian Islamic civilization discussed in the previous section. An even earlier attempt by Iran to revive this particular moment and geography of ancient Silk Roads is the very idea of the Economic Cooperation Organization (ECO), which is a regional integration organization (similar to the idea of ASEAN) that was set up in 1985 by Iran, Turkey, and Pakistan. When put together, the geographies of these three countries resonate with the geography of the Turko-Persian Islamicate cultures of the ninth and tenth centuries. The Economic Cooperation Organization's secretariat is based in Iran. De Cordier (1996) described the logic of this organization as 'New Silk Road', a 'road' intended to create 'a common destiny' (ibid.) for the three countries involved, thus eerily foreseeing the concept of the 'community of common destiny' adopted by the current Chinese President Xi Jinping in recent years.

The rise of the BRI gave a major boost to Iran (among others) in its promotion of the (New) Silk Roads discourse. There are several interesting reasons why Iranian elites have opted to refer to the BRI as the 'New Silk Roads'. First and foremost, it is easier for the audience of this discourse to understand the concept of the 'New Silk Roads' than to understand the new concept of the BRI. When described as the 'New Silk Roads', the Iranian and regional audiences can more readily understand the idea and its global implications. It resonates with both the elite and the general population in Iran. This is because various Iranian empires (such as the Achaemenid, Sassanian, and Sassanid dynasties) had a foundational or instrumental rule in the ancient Silk Roads. The idea of the Silk Roads is part of the collective historical and geographical consciousness of the nation. The role of the country in that world (and the myths therein) is invoked to suggest the promise of the future role of the country in the New Silk Roads, especially in the BRI.

This discourse also provides Iran and its regional or global partners with a common cultural, historical, and geographical language to speak with each other about their (desired) place in this brave new world. Chinese President Xi Jinping's visit to Iran in 2016 included paying a visit to the Iranian leader, Khamenei. During this visit, Xi pointed to the relations and interactions between the two civilizations along the ancient Silk Roads as the basis upon which future cooperation along the New Silk Roads could be built (Office of the Supreme Leader 2016). Iran's spatial assumption, one can infer, is that the Silk Roads constitute the next iteration of human globalization, a world in which Iran could not be sidelined due to the 'the centrality of Iranian geography'. This geographic centrality is a theme that 
comes up in every part of Iranian official geographical discourse and the interviews conducted.

It should be noted that the use of the term 'Silk Roads' by both the Iranian elites and ordinary citizens brings forth an often overly romanticized myth of the ancient Silk Roads. In this myth, it is assumed that Iran reigned supreme, although in reality it did so only at certain times and only over certain parts of that geography. At other moments, Iran was brutally victimized. There is a subconscious selectiveness at work in sidestepping the traumatic moments of history and focusing on the successful empires only. Along the same lines, there is also a selectiveness in the way that Iran has defined 'the East'.

\section{The 'Turn to the East'}

The rise of the New Silk Roads in Iranian official discourse is coterminous with the rise of Asia or 'the East'. Iranian leaders have opted for what has been named the 'turn to the East' or the 'look to the East' strategy as a policy that encompasses Iranian political, economic, and infrastructural involvement in the BRI, as well as in other initiatives such as the International North-South Transport Corridor (INSTC), the Eurasian Economic Union (EAEU), and the Ashgabat Agreement. For Iran, 'the East' was formerly synonymous with the Soviet Empire. However, in more contemporary official discourse, and due in part to the Soviet collapse and the geopolitical realities of Iran (such as the Western sanctions), 'the East' as a geographic discourse has undergone a transformation and taken on positive connotations. It now stands for Asia and represents economic and scientific progress. This progress is especially associated with actors such as China, India, Russia, and Turkey. Iran has pragmatic relations with all of these 'Eastern' actors.

The 'turn' to the East involves relying on foreign relations (both geoeconomically and geopolitically) with these 'Eastern' actors. This is done partly to evade the negative effects of the American sanctions regime, and to develop what has come to be known as the 'resistance economy'. It is also done partly out of cultural familiarity and mutual interests. According to Khamenei, who determines or at least officially greenlights all of Iran's strategic policies, this approach can be described as follows: '[R]egarding the realm of foreign policy, we should prefer the East to the West and neighbours to distant countries. We should choose nations and countries that share common interests with us' (Khamenei 2018b).

China and Iran do not currently lack common interests. This 'turn to the East' is being solidified in the backdrop of a Sino-Iranian 'comprehensive strategic partnership'. This partnership involves the BRI in more ways than 
one. Since Xi Jinping's 2016 visit to Iran, the two countries were rumoured to have been negotiating a comprehensive '25-year deal' or 'roadmap' (see New York Times 2020). This deal is supposed to cover all major areas of cooperation, including the energy sector (oil, gas, and petrochemicals), infrastructure, (multi-modal) transport, sizable investments in Iranian manufacturing, free economic zones (such as the Island of Qeshm), banking, industrial parks, and closer defence and intelligence cooperation in West Asia. The deal is estimated to be worth around US $\$ 400$ billion. The investments are from China to Iran. In return, China gets discounted Iranian energy. The general outline of the deal was confirmed by Javad Zarif, the Iranian Foreign Minister, in July 2020. The full details are yet to be made public. The deal, when finalized, will wed Iran to the BRI. It has divided the country. Some view it as an economic lifeline for Iran (whose economy and currency are at the moment under heavy pressure). Meanwhile, others (especially in popular Iranian social media circles) are very suspicious of the deal, suspicions that in too many cases are articulated through Sinophobic sentiments.

The same division exists with regards to the 'turn to the East' strategy. There are some factions within the ruling elites and the general population that prefer more cultural and economic ties with 'the West'. The ill-fated nuclear deal was carried out by this camp. However, with America reneging on the deal, and the Europeans being unwilling or unable to make a meaningful move independent of the US that would compensate for the damage that the US has introduced to the deal's dynamics, the 'turn to the East' strategy is witnessing increasing momentum. With the 25-year deal between China and Iran in the process of being finalized, this Iranian 'turn to the East' looks almost inevitable. The more pro-'Western' camp has been reduced to silence and compliance. In terms of relations with India and Turkey, there is agreement between all factions (conservative and moderate) that deeper relations with these two actors are positive for the country. Feelings about Russia show the same kind of ambivalence and division as those about China. However, the direction is clear. Iran is both choosing, and being forced by 'the West', to 'turn to the East'. All this is evidence of how relational, malleable, and contingent geoeconomics is.

\section{Iran Reimagining the Region as 'West Asia'}

If the new 'East' is synonymous with 'Asia', what kind of 'middle' does the 'Middle East' occupy as a region? One way in which Iran shows geographic agency has been through reconceiving the region in its official discourse 
as 'West(ern) Asia'. This is one of the most explicitly articulated examples of Iranian geographic agency that has been implemented in a top-down fashion, starting from the highest political-religious power in the country, the Iranian leader himself. From his office, this regional renaming discourse has percolated down to other political, economic, and media organizations. Khamenei never refers to the region as the Middle East in his speeches. The same is true for online archives, websites, and social media accounts associated with him or representing him or his office. In a 2012 speech to an academic audience, he made his geographic reasoning clear:

I insist on calling this region 'West Asia', not 'Middle East'. The terms 'Far East', 'Near East' and 'Middle East' are not correct. Far from where? From Europe. Near to where? To Europe. This implies that Europe is the centre of the world. [...] This is a definition that was presented by Europeans themselves, but this is not acceptable to us. Asia is a continent. It has an eastern part, a western part and a middle part. We are in the western part. Therefore, our region should be called 'West Asia', not 'Middle East'. (Khamenei 2012)

There are several aspects of this quote that are interesting. First it provides an accurate historical narrative of the origins of the term 'Middle East'. According to Beaumont et al. (1976: 1), the term Middle East was developed out of a 'strategic preference' in a 'Eurocentered world just as the older terms "The East”, "Far East”, and "Near East" had been' (ibid.). 'The Middle East' seems to have originated in the 1850 s in the British imperial office. It became 'current in the English-speaking world around 1900' (ibid.). Second, this is a surprisingly progressive view of geography from a conservative religious leader. In today's academic circles, especially the critical strands of the social sciences, Eurocentric or Orientalist views of global history and geography are being radically questioned (see Van der Pijl 2007 and Said 1979, respectively). For Iran, one can infer from the discourse that part of the logic of jettisoning the term 'the Middle East' is to do away with all the negative Orientalist connotations associated with the term and (re-)associate the region with Asia. Getting rid of the term aims to remove the vestiges of the imperialistic geographic imagination that named this geography 'the Middle East' and to rebrand the region in a new light. This is a clear sign that Iranian elites consciously and explicitly are aware of the constructed nature of geography and are actively engaged in the making of both the discursive and material geography of the country and the region. This is an instance of Iranian elites exercising their geographic agency. Apart from 
the push to call the region 'West Asia', other examples of this kind of agency are the creation and promotion of geopolitical terms such as the 'axis of resistance', a term used by Iranian elites to refer to Iran and its (state and proxy) allies in resisting American hegemony in the region.

It is therefore no surprise that the term 'West Asia' is being increasingly used by Iran and several other actors in the region and the rest of Asia. Among others, Chinese, Indian, Iranian, Turkish, and some Arab official discourses also refer to the region as 'West Asia', especially in their interaction with each other. In the official United Nations demarcations of regions in the world, 'Western Asia' is the official designation for this region. What is more, one of the six official economic corridors of the BRI that passes through the region is China-Central Asia-West Asia (CAWA) Corridor. In official discussions across Asia, the 'West Asia' discourse has gained increasing momentum since the advent of the BRI and the emergence of a Silk Roads geographic imaginary, especially when the interlocutors in these discussions are all from Asia.

One can argue that the rise of this 'West Asia' discourse shows the geographic agency of a whole region, or even a continent, that aims to rename and reclaim this region as part of Asia and the Asian heritage. It should however be noted that just as the choice of 'the Middle East' was a Western strategic and military choice, the choice of 'West Asia' made by Iran and other Asian actors is also a strategic choice. As the former Western discourse negatively (geo)politicized the region for (neo)colonial purposes, the new 'West Asia' discourse is also aiming to (geo)politicize the region (albeit in a way that is beneficial to Asian actors). This latter naming discourse is yet another political project that does not aim to separate geography from power relations. It aims to reclaim power.

\section{Iran Reimagining Itself as a 'Civilizational Crossroads'}

If contemporary Iranian geographic agency contends that the emerging global geography is a (New) Silk Roads geography, in which 'the East' or Asia is rising, and if the region is not 'the Middle East' but 'West Asia', then what is Iran? What kind of space-making assumptions and space-making processes or policies is Iran in the business of promoting or implementing about its role in the emerging regional or global geography? Such assumptions include, first, the idea of 'greater Iran' as a 'civilizational state' and, second, the idea of Iranian geography as a 'civilizational crossroads'. Three processes or policies that are being carried out in order to make the crossroads dream 
a reality are 'port connectivity policies', 'the railway revolution', and the international 'geoeconomic connectivity push'. These policies all result in international pacts, agreements, and initiatives. In what follows, I will briefly elaborate on the two assumptions about the identity of Iran and the three processes to which they lead.

\section{Space-Framing Assumptions: 'Greater Iran' as the 'Civilizational Crossroads'}

One common theme that appears in official Iranian discourse (politically and academically) is the idea of 'greater Iran', sometimes also called 'greater cultural Iran'. The expression is common among Western classicists and means 'that which was within the political boundaries of states ruled by Iran, including Mesopotamia and usually Armenia and Transcaucasia' (Frye 1962: 241). The term is clearly an academic one, but it seems that Iranian political elites have picked up on this academic discourse and are using it as a cultural and economic category. One of the strategic edicts that Khamenei has given the Iranian elites is to conduct what he calls 'public diplomacy'. This involves activities such as gathering the (academic and cultural) elites of 'West Asia' together for dialogue in Iran. He places special emphasis on the elites of the 'greater cultural Iran, that is the vast cultural geography of Iran in previous centuries' (Khamenei 2018a). This is therefore a demarcation of Iranian boundaries that goes beyond the Westphalian notions of Iran and views the Iranian geography as culturally, historically, linguistically, and religiously rooted in the pre-Islamic and Islamic imperial geographies of the country. The hegemonic ambitions beyond the idea of 'greater Iran' is hard to miss here. This idea is not very different from Axworthy's (2008) description of Iran as an 'empire of the mind'.

One can see that Iran is once more delving deep in its ancient preWestphalian history in order to dream of a future for itself in what it calls the 'post-Western world' (Zarif 2016) of Silk Roads. Along the same lines, in a 2018 UN speech Iranian President Hassan Rouhani rejected accusations that Iran is after geopolitical domination of the region by describing his country in the following terms: 'Iran does not need an empire. Iran is an empire, in terms of its civilization and culture. Not through political domination. Iran has served as the link between East and West and will continue to do so' (Rouhani 2018). The two themes or assumptions that frame Iran are evident: Iran as a 'link' or 'crossroads', and Iran as a 'civilization'. The discourse has not been hierarchically produced. It is part of what, in the theory section of this chapter, was called an 'organic social transformation'. Most Iranians 
of all walks of life understand their country in terms that go beyond the Westphalian geographic imaginary of nation states. For some the frame of reference is the Islamic traditions of the past, while for others it is the pre-Islamic imperial traditions of Iran, and then for a third group it is a combination of both. An example of the latter is former President of Iran Mahmoud Ahmadinejad, who tried, in vain, to push both banners of the Islamic and pre-Islamic Iran. These two discourses are not limited to any specific faction within Iran. They usually co-exist in the official discourses and are employed on an as-needed basis.

In the meetings between Iranian and Chinese leaders, the civilizational discourse is abundant. At the very beginning of the negotiation documents for the '25-year deal', for instance, there are references both to the 'greatness' of the Iranian and Chinese civilizations in the past and also to how their contemporary cooperation, including in the BRI context, is 'natural'. I would argue that the numerous references to the 'Iranian civilization' and 'Persian cultural heritage' in documents amounts to calling Iran a 'civilizational state'. The idea of such civilizational states is gaining increasing discursive momentum in Asia. Zhang (2012), for example, calls China a 'civilizational state' (his eponymous book became a bestseller in China). Meanwhile, Kumar (2002) calls India a 'civilization-state'. One can only infer that this is the discursive tool these actors choose to use in order to make sense of their long and complex history and geography in a Westphalian system of 'nation states' that is less than 500 years old. Without using this term explicitly, the Iranian discourse of 'greater Iran' is making a very similar geographical-historical-political move. Not only does Iran see itself as a 'civilization', but it sees itself as one whose identity is that of a 'link' or 'crossroads' between various other civilizations, economies, and cultures.

\section{Space-Making Processes: Connectivity Policy Drive, Port Modernization, and Railway Revolution}

In what follows, I will examine some of the policies and processes that Iran is actively pursuing in order to make its dream of being a 'civilizational crossroads' dreams become a reality. The first process discussed here is what can be called Iran's international 'geoeconomic connectivity drive'. It dates back to the early years of the Iranian Revolution of 1979 and aims to geoeconomically connect the country with the region and beyond. Immediately after the revolution, Iran initiated talks concerning founding the Organization for Economic Cooperation (ECO), which was discussed above. Turkey and Iran are particularly interested in the prospect of signing a free 
trade agreement under the auspices of this organization or in the form of a free trade agreement.

Iran has also enthusiastically welcomed the BRI and is considered an integral part of the CAWA Corridor. This is the least developed corridor of those in the BRI. Its lack of development is due in large part to the geopolitical complexities of the region and the conflicting geoeconomic and policy interests of regional actors, which are too numerous to unpack here. After the Joint Comprehensive Plan of Action (the Iran Nuclear Deal) came into effect in 2015, the Chinese President Xi Jinping was the first foreign leader of a major country to visit Iran, rushing to the country and signing seventeen economic and security agreements and MoUs, covering the various dimensions of the BRI. During the trip, Xi emphasized the 'geographic, human, and energy' potential of Iran. It is not an accident that Iranian geography plays such a central role in the discussions between the two countries' leaders. This geographic awareness exists among both Chinese and Iranian political and economic elites. According to the Iranian President, China and Iran signed the preliminary version of a 'comprehensive 25-year document' (discussed briefly in the previous section). This document indicates how seriously China takes the question of Iran in the three areas that Xi pointed to. This close partnership between China and Iran has been referred to by American observers as China's 'Great Game' in Iran'. Such a description, however, assigns too much agency to China and too little to Iran. The former is portrayed as an all-powerful evil actor and the latter as a victim in this kind of analysis.

However, dealing with the BRI and China is not the only game in town for Iran. Iran was a founding member of the International North-South Transport Corridor in May 2002. India is currently the main drive behind this initiative. Effectively, one might call this the Indian Silk Roads. India has given this initiative serious attention since the BRI was introduced. The role of Iran and the Chabahar Port (discussed below) is indispensable in this initiative. Iran is also a major trade partner of the Russian geoeconomic initiative, the Eurasian Economic Union (EEU). Iran and the EEU signed a free trade agreement in 2018, to be operationalized from 2021. The two countries have also signed a preferential trade agreement, which has already boosted trade between them to some extent. All these geoeconomic initiatives also connect to the Ashgabat Agreement, in which Iran has a pivotal role due to the centrality of its physical geography. Geopolitics (for instance, American sanctions) has very negatively affected and slowed down these processes. However, Iran's geoeconomic foundations have been solidified enough to ensure that its role in these processes and initiatives cannot be denied. 
The second space-making process that Iran is involved in is 'port modernization'. Ports across Asia are gaining significant attention in the context of the BRI, of the International North-South Transport Corridor, and other initiatives. Iran, given its well-connected geography in the region, is no exception. This dimension of Iranian geography involves several ports, such as Bandar Anzali and Astara in the north and Bandar Imam Khomeini, Bandar Abbas, Bushehr, and Chabahar in the south. Due to the limited scope of this chapter, I will briefly focus on Chabahar and its role as the only deep water port in Iran that is officially associated with all the major initiatives mentioned in this chapter, especially the BRI and the International North-South Transport Corridor.

In 2016, after years of negotiations, Iran, Afghanistan, and India signed a trilateral connectivity pact, the centrepiece of which is Chabahar Port in south-eastern Iran. This pact shows the geographic agency of all these three countries. All three countries are trying to overcome specific geographic challenges (for example, the issue of being landlocked for Afghanistan) and produce new geographic opportunities for themselves. At the signing ceremony in Tehran, Ashraf Ghani, Afghanistan's President, said the following words in the presence of Rouhani and Narendra Modi: 'We wanted to prove that geography is not our destiny. With our will, we can change geography' (Financial Times 2016). If there were to be one definition of 'geographic agency', this could be it. Changing geography is part of a dominant global trend that Khanna (2016) calls 'connectography'. This can be defined, to use the Ghani quote, as the will to change one's geography, and therefore to change one's destiny, by creating new types of geographic, cultural, economic, energy, and political connectivity.

Chabahar Port is supposed to connect India via Iran to Afghanistan, so that Indian exports do not have to go through Pakistan. In terms of land access to the rest of Asia, the Caucuses, Russia, and Europe, Chabahar is now and for the foreseeable future the only reliable option that India has. This fact makes the Iranian geography indispensable for India. Chabahar is, in the words of the Indian Prime Minister Narendra Modi, a 'golden gateway' for India (Bhattacharjee 2018). Indian officials feel that the Chinese BRI has geopolitical and containment elements against India. They want to create India's own geoeconomic Silk Roads, if you will. This Indian dream, however, is completely dependent on passing through Iran. Other options would be going through either Pakistan or China, which Indian officials do not find ideal for obvious geopolitical reasons. Here, geopolitics is producing unique geoeconomic realities. This is something that Iranian elites are taking advantage of by further deepening their ties with India and bringing Indian investment to Chabahar 
Port to further develop it. As the only Iranian deep water port, Chabahar can potentially rival the Pakistani port of Gwadar (the two ports are close to each other). Gwadar is the centrepiece of the China-Pakistan Economic Corridor.

Ports are nothing if not connected to other major cities. India is therefore investing in the Chabahar-Zahedan Railway. Zahedan is the closest major Iranian city to Chabahar. This brings us to Iran's third space-making process or national policy intended to materialize the idea of Iran as a geographical and civilizational 'crossroads'. This involves building new railway lines and upgrading old ones, a process described by some as the 'Iranian railway revolution' (Alterman \& Hillman 2017). The role of this railway upgrade is first and foremost to adapt and prepare the country for the BRI, which is heavily focused on railway transport technology. China is leading a 'high-speed railway revolution' in the world that is positively impacting its economic development (Chen et al. 2016). Iran is trying to catch up with the railway trend and is thus heavily dependent on China for this upgrade. For the BRI corridor to West Asia, China and Iran have already made operational a direct train connection. A train arrived in Iran from China for the first time in 2016. In 2018, another connection was established. The documents setting out the '25-year deal' between Iran and China emphasize and promise large investments in the transportation field, especially in railways.

China is not the only destination for Iranian railway. The Iranian railway network is connected to almost all neighbouring railway networks. According to a report provided by Abbas Nazari, ${ }^{2}$ networks that the Iranian rail system is connected to include those in Azerbaijan, Turkey, Pakistan, and the Indian subcontinent. The network also has Imam Khomeini Port's railway connection to international waters for multimodal transport, as well as the Bandar Abbas connection to international waters (it is also part of Bandar Abbas-Almaty Corridor). Then there is Amir Abad's railway connection to the Caspian Sea, Turkmenistan, and the Commonwealth of Independent States (CIS), which practically connects Iran to Central Asia, Russia, and Eastern European networks. In 2018, Rouhani also officially opened the rail connection to Iraq. There are currently two routes between Iran and China. The first passes through Kazakhstan, Uzbekistan, and Turkmenistan. The second takes a similar route that bypasses Uzbekistan. It is therefore not a surprise that the International Union of Railways (UIC) has its Middle East Office in Tehran, of which Abbas Nazari of Iranian Railways (RAI) is

2 Abbas Nazari is at the time of writing the Director General of the International Affairs Bureau of Iranian Railways and Director of the UIC Middle-East Regional Office, which is based in Tehran. 
currently the head. In 2019, Iran held the UIC's 7 th Nextstation Conference, which was described as 'the global reference for leaders and decision makers to share the latest experiences and best practices regarding the design, financing and operation of railway stations' (UIC 2019). Such proactive events and moves by Iranian Railways has increased familiarity, interest, and investment in Iran's railway network.

Iranian Railways (RAI) as an institution has been very proactive and shown systematic geographic agency by holding such conferences as well as bilateral or multilateral meetings as part of the country's railway revolution and connectivity drive. It is also in the process of developing seven new railway projects inside the country. The high-speed rail between TehranQom-Isfahan is the showpiece of the whole network, financed and under construction by China and officially associated with the BRI. Construction started in 2015 but is facing delays due to sanctions and other issues. Interestingly, RAI's maps of Iran's current and planned railway network on its official website refers to Iranian connectivity to Europe and China in terms of the 'Silk Road' (see, for instance, Alterman \& Hillman 2017). It can therefore be argued that institutions such as Iranian Railways are involved in the making of geography both in the material sense (the physical railway) and the ideational sense (the Silk Roads vocabulary). Such activities, policies, and institutional undertakings speak of the fact that discourses constitute and make realities and are not merely figments of imagination.

\section{Conclusion: Iran between Geopolitics and Geoeconomics}

As an international actor, Iran is viewed in both the global mass media and academic literature in political science and international relations as an almost exclusively geopoliticized country. In such literature, the geoeconomic processes and policies of the country are, more often than not, ignored. The Iranian geographic imagination has also not been critically assessed either. This chapter was an attempt to compensate for this dual gap in the literature.

Since the 1979 revolution, Iranian elites have been trying to geoeconomize the country by coming up with the plans and initiatives that were discussed above. The geoeconomic drive has been boosted considerably since the advent of the BRI. Iran is increasingly aligning its destiny with the geoeconomics of Asia, and especially with the Chinese BRI. The recent official acknowledgements of the Sino-Iranian '25-year deal' point to one conclusion: Iran, with its vast and central geography and its steady partnership with China, has become 
the centrepiece of China's West Asian policy and the most important piece, one could argue, of the BRI's CAWA Corridor. A question remains, however, about how lopsided Iranian reliance on China and the BRI will be. To avoid this lopsidedness, Iran has made itself an indispensable part of the International North-South Transport Corridor and the Ashgabat Agreement, as well as an important partner for the Eurasian Economic Union. Such geoeconomic processes can potentially help geoeconomize certain regions such as West Asia, Central Asia, or certain actors such as Iran or Pakistan, which have been geopoliticized in the dynamics of the last century (see Forough 2019).

Currently, geopolitical processes (mainly American unilateralism) are making this transformation slow and complicated. However, the trend in the past three decades has been one in which Iran has made itself integral to Eurasian geoeconomics. In this emerging world, functional infrastructure can say much more about how the world operates than Westphalian political borders. Contemporary maps should show highways, railways, ports, airports, pipelines, communications lines, as well as paths of contagion and other risks, instead of merely showing political borders (Khanna 2016). Iranian geographic discourse, in a major multi-pronged effort to plug the country into this dynamic geoeconomic world, selectively picks and chooses elements, events, or processes from its long history (both Islamic and pre-Islamic) and geography in order to create a coherent narrative about the country's role in the world. Thanks to the BRI and other initiatives discussed above, the idea of Iran, for now at least, is turning into one of a 'civilizational crossroads', in a region it chooses to call 'West Asia', in a world in which the principal organizing trope, geographically and historically speaking, is that of the (New) Silk Roads. As opposed to the 'neither West nor East' narrative of the 1979 Iranian Revolution, Iran is currently shooting off in all directions, 'East' and 'West' as well as 'North' and 'South', in the hope of someday becoming a fully fledged crossroads.

\section{References}

Agnew, John (1994). 'The Territorial Trap: The Geographical Assumptions of International Relations Theory'. Review of International Political Economy, 1(1), 53-80. Alterman, Jon B. \& Hillman, Jonathan E. (2017, May 10). 'Iran's Railway Revolution'. Reconnecting Asia/Center for Strategic \& International Studies (CSIS). Retrieved 28 September 2020 from https://reconnectingasia.csis.org/analysis/entries/ irans-railway-revolution/.

Axworthy, Michael (2008). Iran: Empire of the Mind: A History from Zoroaster to the Present Day. London: Penguin. 
Berkowitz, Mark. (1996). World's earliest wine. Archaeology, 49(5), 26-26.

Beaumont, Peter, Gerald H. Blake, and J. Malcolm Wagstaff (1976). The Middle East: A Geograghical Study. London: John Wiley and Sons

Bhattacharjee, Kallol (2018, February 18). 'Chabahar Will Be a Golden Gateway, Says Narendra Modi'. Retrieved 28 September 2020 from: https://www.thehindu. com/news/national/chabahar-will-be-a-golden-gateway-says-narendra-modi/ article22786234.ece.

Bilgin, Pinar (2010). 'The "Western-Centrism" of Security Studies: "Blind Spot" or Constitutive Practice?' Security Dialogue, 41(6), 615-622.

Calder, Kent E. (2012). The New Continentalism: Energy and Twenty-First-Century Eurasian Geopolitics. New Haven, CT: Yale University Press.

Canfield, Robert Leroy (ed.) (2002). Turko-Persia in Historical Perspective. Cambridge: Cambridge University Press.

Chen, Zhenhua, Junbo Xue, Adam Z. Rose, and Kingsley E. Haynes (2016). "The impact of high-speed rail investment on economic and environmental change in China: A dynamic CGE analysis." Transportation Research Part A: Policy and Practice 92: 232-245.

Daniel, Elton L. (2012). The History of Iran. Santa Barbara, CA: Greenwood.

De Cordier, Bruno (1996). 'The Economic Cooperation Organization: Towards a New Silk Road on the Ruins of the Cold War?' Central Asian Survey, 15(1), 47-57. Forough, Mohammadbagher (2019). 'Intervention with Chinese Characteristics: The Belt and Road Initiative Reconfiguring (Afro-) Eurasian Geo-economics'. Conflict, Security \& Development, 19(3), 275-281.

Frankopan, Peter (2015). The Silk Roads: A New History of the World. London: Bloomsbury. Frye, Richard Nelson (1962). 'Reitzenstein and Qumrân Revisited by an Iranian'. Harvard Theological Review, 55(4), 261-268.

Financial Times (2016, May 24). 'India to Bypass Pakistan on the Road to Central Asia'. Financial Times. Retrieved 28 September 2020 from https://www.ft.com/ content/8510176c-2188-11e6-9d4d-c11776a5124d.

Gnoli, Gherardo (1989). The Idea of Iran: An Essay on Its Origin. Roma: Istituto Italiano per il Medio ed Estremo Oriente.

Guzzini, Stefano \& Leander, Anna (2006). 'Wendt's Constructivism: A Relentless Quest for Synthesis'. In Stefano Guzzini \& Anna Leander (eds.), Constructivism and International Relations: Alexander Wendt and His Critics (pp. 73-92). London: Routledge.

Hansen, Valerie (2012). The SilkRoad: A New History. Oxford: Oxford University Press. Harvey, David (2006). Spaces of Global Capitalism. London: Verso.

Khamenei, Ali (2009, March 10). 'Leader Meets with Turkish President'. Khamenei. ir. Retrieved 28 September 2020 from http://english.khamenei.ir/news/106o/ Leader-Meets-with-Turkish-President. 
Khamenei, Ali (2012, August 12). 'Leader's Speech to Professors'. Khamenei.ir. Retrieved 28 September 2020 from http://english.khamenei.ir/news/1661/ Leader-s-Speech-to-Professors.

Khamenei, Ali (2018a). 'Bayaanaat dar Didaare Nokhbegan va Estedaad-haaye Elmi' [Speech to academic and scientific elites]. Khamenei.ir. Retrieved 28 September 2020 from http://farsi.khamenei.ir/speech-content?id=43719.

Khamenei, Ali (2018b, February 12). 'Preference of East over West Is a Priority for Iran'. Khamenei.ir. Retrieved 28 September 2020 from http://english.khamenei.ir/ news/5487/Preference-of-East-over-West-is-a-priority-for-Iran-Imam-Khamenei.

Khanna, Parag (2016). Connectography: Mapping the Future of Global Civilization. New York: Random House.

Kumar, Ravinder (2002). 'India: A “Nation-State” or “Civilisation-State”?' South Asia:Journal of South Asian Studies, 25(2), 13-32.

Larkins, Jeremy (2010). From Hierarchy to Anarchy: Territory and Politics before Westphalia. New York: Palgrave Macmillan.

Malandra, William W. (2005). 'Zoroastrianism i. Historical Review up to the Arab Conquest'. In Encyclopedia Iranica. Retrieved 28 September 2020 from https:// iranicaonline.org/articles/zoroastrianism-i-historical-review.

New York Times (2020). 'Defying US, China and Iran Near Trade and Military Partnership'. New York Times. Retrieved 28 September 2020 from https://www. nytimes.com/2020/07/11/world/asia/china-iran-trade-military-deal.html.

Office of the Supreme Leader (2016). 'Ayatollah Khamenei: Iran-China 25-Year Strategic Agreement a Wise Move'. Retrieved 28 September 2020 from https:// www.leader.ir/en/content/14066/www.leader.ir.

Peet, Richard (2000). 'Celebrating Thirty Years of Radical Geography'. Environment and Planning $A$, 32(6), 951-953.

Rachman, Gideon (2017). Easternization: Asia's Rise and America's Decline from Obama to Trump and Beyond. New York: Other Press.

Rouhani, Hassan (2018). 'Full text of Iran's President Rouhani Speech at UNGA 73'. The Iran Project. Retrieved 28 September 2020 from https://theiranproject. $\mathrm{com} / \mathrm{blog} / 2018 /$ og/25/full-text-of-irans-president-rouhani-speech-at-unga-73/.

Said, Edward (1979). Orientalism. New York: Vintage Books.

Selden, Daniel (2013). 'Iskander and the Idea of Iran'. In Tim Whitmarsh \& Stuart Thomson (eds.), The Romance between Greece and the East (pp. 142-161). Cambridge: Cambridge University Press.

Sparke, Matthew (2007). 'Geopolitical Fears, Geoeconomic Hopes, and the Responsibilities of Geography'. Annals of the Association of American Geographers, 97(2), 338-349.

UIC (2019). 'UIC and Iranian Railways (RAI) Have Successfully Organised the 7 th UIC Nextstation Conference in Tehran under the Theme Railway Stations Boosting 
the City'. International Union of Railways (UIC). Retrieved 28 September 2020 from https://uic.org/com/uic-e-news/668/article/uic-and-iranian-railways-raihave-successfully-organised-the-7th-uic?page=modal_enews.

Van der Pijl, Kees (2007). Nomads, Empires, States. London: Pluto Press.

Zarif, Javad (2016). Doraan-e Gozaar dar Ravaabete Beinolmelal dar Donyaaye Pasaagharbi [The transition in international relations of the post-Western world]. Tehran: Center for International Research and Education.

Zhang, Wei-Wei (2012). The China Wave: Rise of a Civilizational State. Singapore: World Scientific.

\section{About the Author}

Mohammadbagher (MAmad) Forough is University Lecturer in the International Relations of Modern Iran at Leiden University and a LeidenAsiaCentre fellow. His research is, broadly speaking, focused on geoeconomic and geopolitical shifts at the global level (i.e. the retreat of the West and the rise of the rest, especially China and India, at the global level and Iran at the regional level). Theoretically focused on critical geography, he investigates how the elements of 'geo' (namely, geographical factors, connectivity, infrastructure projects, and geographic discourse) and 'politics' and 'economics' mutually affect and are affected by each other when it comes to theories of geopolitics and geoeconomics. Together with Frans-Paul van der Putten, he initiated the Clingendael Institute's Silk Road Headlines, a weekly news service providing updates on news articles related to China's Silk Road initiative. 
